\title{
Does Philips Relations Really Exist in Nigeria? Empirical Evidence
}

\author{
Taiwo V. Ojapinwa ${ }^{1} \&$ Folorunso Esan ${ }^{2}$ \\ ${ }^{1}$ Department of Economics, Lagos State University, Ojo-Lagos, Nigeria \\ ${ }^{2}$ Department of Economics, University of Lagos, Akoka-Yaba, Lagos, Nigeria \\ Correspondence: Taiwo V. Ojapinwa, Department of Economics, Lagos State University, Ojo-Lagos, Nigeria. Tel: \\ 234-803-417-2740. E-mail: ojapinwataiwo@gmail.com
}

Received: May 21, 2013

Accepted: July 29, 2013

Online Published: August 26, 2013

doi:10.5539/ijef.v5n9p123

URL: http://dx.doi.org/10.5539/ijef.v5n9p123

\begin{abstract}
The paper examines the existence and the stability of Phillips relations for Nigeria, using time series data from 1970 to 2010. Graphical, Augmented Dickey Fuller and Philip Peron unit root tests were employed to check for stationarity. ARDL and DOLS general to specific approaches to cointegration have been used to explore the Philips relations and ECM to understand short run dynamics. The estimates shows that relation between the change in inflation rate and the unemployment rate is theoretically negative in the short run-a low unemployment rate leads to an increase in the inflation rate and therefore an acceleration of the price levelhowever, the relation became non existence in the long run with positive relationship between inflation and unemployment signifying stagflation. Meanwhile, recursive residual, CUSUM and CUSUMsq tests confirm a stable Philips relation.
\end{abstract}

Keywords: Phillips Curve, dynamic model, ADF, cointegration, DOLS, Nigeria

\section{Introduction}

Fifty four years ago, A. W Phillips plotted nominal wage inflation against unemployment in the United Kingdom, and remarked on their tight and stable negative relation over the previous century. Twenty-five years after Phillips's paper, Robert Lucas and Thomas Sargent set the simultaneously high inflation and unemployment evident across practically all developed economies - against a Phillips curve backdrop and decried the econometric failure on a grand scale. This followed a sequence of papers during the 1970s that had both supported and called into question the econometric and theoretical basis of the Phillips curve and hence its usefulness for public policy purposes (Lipsey, 1960; Solow, 1970; Onder, 2004 and Faridul et al, 2011).

The possibility of a trade off offers policymakers a tool to deal with macroeconomic disequilibrium. However, the failure to explain economic crises of the 1970s had cast serious doubts about the validity of the relation. While Phelps (1967), Friedman (1968), Lucas (1976) and Okun (1975) argued against the hypothesis, Onder (2004), Kustepeli (2005), Furuoka (2007), Tang and Lean (2007), Schreiber and Wolters (2007), Dammak and Boujelbene (2009) lent support to a stable non linear relation. Others found an unstable relation between unemployment and inflation (Lucas, 1972, 1973, 1976); Okun (1975); Turner (1997); Atkeson and Ohanian (2001); Niskanen (2002); Demers (2003) and Reichel (2004).

Akerlof et al. (1996, 2000), Karanassou et al. (2005), and Holden (2004) discuss models in which long-run trade-off between output and inflation can exist if the inflation rates are low. Karanassou et al. (2003) provides support to a long-run inflation-unemployment trade-off for some EU countries; and Franz (2005) for German. Thus whether or not a long-run inflation-unemployment trade-off exists should be left to empirical tests using appropriate tools. This may help clarify some of the mysteries underlining the relationship between inflation and unemployment (Mankiw, 2001).

Much of the existing literatures have been examined within the context of developed countries. According to Faridul et al, sound macroeconomic policy is considered critical for pursuing economic growth and this is more relevant for African countries which are more vulnerable to major shocks. The objective of this study is therefore to analyse both the existence and stability of Philips relation in Nigeria. Since we are not aware of any study purporting to or that has explored these issues for Nigeria using annual data from 1970 to 2010 the research thus fills a gap in knowledge and thus contributes to the literature. 
The rest of study is organized as follows. Literature review is discussed in Section II. Section III describes the methodology. Findings are discussed in section IV. Conclusions and policy implication are drawn in Part V.

\section{Literature Review}

The high rate of both inflation and unemployment experienced by many countries in the 1970s brought about concerted attacks on Philips curve as Friedman (1968) argues that this relationship was only a short run phenomenon. In the long run according to Friedman, workers and employers takes inflation into account result in employment contracts that increase pay at rates near anticipated inflation. This implies that over the long run, there is no trade-off between inflation and unemployment. Niskannen (2002) points out that the Philips curve in its original form suffers misspecification and that the positive slope of the long run Philips relation may be due to lack of indexed tax code. Gali et al, (2005) and Rudd and Whelan (2005) use GMM approached but failed to find strong Philips relation. Reichel (2004) applied co integration method to the industrialised economies but found trade-off only for US and Japan.

However, Karanassou et al, consistently provide further support for long run inflation-unemployment trade-off. For instance, their work in 2003 for some EU countries provides further support for long run inflation-unemployment trade-off. Karanassou, et al (2008) also analyses the relation between US inflation and unemployment from the perspective of 'frictional growth'. In particular, they focus on the interaction between money growth and nominal frictions and conclude that monetary policy has not only persistent, but permanent real effects, giving rise to a long-run inflation-unemployment tradeoff. Karanassou, et al (2010) employ the chain reaction theory (CRT) approach within the new Phillips curve to provide a synthesis of the traditional structural macroeconometric models and the (structural) vector autoregressions. Karanassou, et al again show that frictional growth, i.e. the interplay between lags and growth, generates an inflation-unemployment trade-off in the long run. They therefore suggest that a holistic framework, such as the chain reaction theory (CRT), should be used to jointly explain the evolution of inflation and unemployment.

DiNardo and Moore (1999) used a panel of OECD countries with ordinary Least Square (OLS) and Generalised Least Square (GLS) methods and found the Philips relation. These finding are corroborated by the work of Malinov and Sommers (1997) and Turner and Seghezzea (1999), where they both employed Seemingly Unrelated Estimation method. Eliasson (2001) specified linear Phillips curve for Sweden, Australia, and the United States and checked for parameters stability. They did not find the Phillips curve for Australia and Sweden, but found one for the US. Unlike Islam et al. (2003) who revisit the US Philips relation using 1950-99 data but did not find a strong relation.

Lipsey (1960) found an inverse relation for Britain for 1914-18, but not after the War. Turner (1997) argues that structural break since the 1970s in Britain may have caused the instability of the Phillips curve. He emphasizes more on the stability, than its existence. Atkeson and Ohanian (2001) also support Turner. Hansen and Pancs (2001) found inverse relation between the series for Lativa. Bhanthumnavin (2002) finds the Phillips curve for Thailand, but only in the post 1997 Asian flu. Graham and Snower (2002) demonstrate a stable Phillips curve for Chile. They argue that the trade off in long run is due to inter-relation between money growth and rise in nominal wages. Using Stock-Watson procedure, Furuoka (2007) found relation between inflation and unemployment for Malaysia, which was later confirmed by Tang and Lean (2007). Schreiber and Wolters (2007) applied VAR cointegration approach and found a long run relation for German.

Cruz-Rodriguez (2008) found Phillips curve for Dominican Republic. However, the link with output gap is found positive, which may be due to world oil prices and exchange rate shocks. Del Boca et al. (2008) found Phillips curve for Italy for 1861-1998. The paper captures the effects of structural changes and asymmetries on the estimates of the trade-off relation and found that a trade-off exists only during low inflation and stable aggregate supply. Russell and Banerjee (2008) investigate vertical Phillips curve assuming non-stationarity in the series. They find positive relation between inflation and unemployment rate in short run for the United States. Paul (2009) argues that droughts, oil shocks and liberalization-policy of the early 1990s may be the reason for the absence of a Phillips curve in India. After adjusting for the shocks he finds the Phillips curve suggesting a short-run trade-off between inflation and industrial output for India. Recently, Faridul et al (2011) estimates a Philips curve for North Cyprus using ARDL bounds testing and Dynamic Ordinary Least Squares (DOLS) approaches. Their results also confirm trade-off between inflation and unemployment.

Focusing on regimes of inflation and unemployment and using the statistical technique of fuzzy clustering, Ormerod et al, (2013) explored for the United States, the United Kingdom and Germany between 1871 and 2009. They reported that the factors which govern the inflation/unemployment trade-off are so multi-dimensional that it is hard to identify periods of short-run Phillips curves which can be assigned to particular historical periods 
with any degree of accuracy or predictability. They therefore identify for each country three distinct regimes in inflation/unemployment space and found that similarities exist across countries in both the regimes and the timings of the transitions between regimes. Further, even within a given regime, the results from the cluster analysis reveal persistent fluctuations in the degree of attachment to that regime of inflation/unemployment observations over time. Their implies that, first, the inflation/unemployment relationship or Phillips curve experiences from time to time major shifts. Second, that it is also inherently unstable even in the short run. They however conclude that, the typical rates of inflation and unemployment experienced in the regimes are substantially different.

\section{Methodology}

The methodology used here is based on the recently developed autoregressive distributed lag (ARDL) framework (Pesaran \& Shin, 1995, 1999; Pesaran et al, 1996; Pesaran et al, 1998) which does not involve pre-testing variables, thereby obviating uncertainty. Put differently, the ARDL approach to testing for the existence of a relationship between variables in levels is applicable irrespective of whether the underlying regressors are purely $1(0)$, purely I(1). The statistic underlying the procedure is the Wald or F-statistic in a generalised Dickey-Fuller regression, which is used to test the significance of lagged levels of the variables in a conditional unrestricted equilibrium correction model (ECM) (Pesaran et al., 2001: 1). The estimates obtained from the ARDL method of cointegration analysis are unbiased and efficient given the fact that: (a) it can be applied to studies that have a small sample, such as the present study; (b) it estimates the long-run and short-run components of the model simultaneously, removing problems associated with omitted variables and autocorrelation; (c) the ARDL method can distinguish between dependent and independent variables.

Researchers have included variables such as real GDP and marginal cost of production in estimating Phillips curve. Gordon (1981) recommends using real gross national product for unemployment rate. To measure inflation consumer price index (CPI) has been used. Overall inflation rate through CPI is a better measure for inflation rate for a developing economy (Faridul et al, 2011). Open unemployment data, real gross domestic products and money supply through M2 are employed for this study. While all data are sources from the Central Bank of Nigeria statistical bulletin and annual reports and statement of accounts (2010) and National Bureau of Statistics (2010), money supply is from the World Development indicators (2010).

The study employed data from 1970-2010 and before implementing co integration technique, the variables used in the model are subjected to stationary tests using Augmented Dickey-Fuller (ADF) and Philip Perron test following equation 1 . Our $\mathrm{ADF}$ test consists of estimating the following equation:

$$
\Delta Y_{t}=\alpha+\beta_{t}+\delta Y_{t-1}+\Psi \sum_{i=1}^{m} \Delta Y_{t-1}+\varepsilon_{t}
$$

Where $\alpha$ represent the drift, $t$ represents deterministic trend, $\beta, \delta, \psi$ are parameters to be estimated, m (lag length) is a lag large enough to ensure that $\varepsilon_{\mathrm{t}}$ is a white noise process; and $\Delta$ is the difference operator. In the ADF approach, we test whether $\delta=0$

The Philips-Perron test is based on the following statistic:

$$
\tilde{t}_{\alpha}=t_{\alpha}\left(\frac{\gamma_{0}}{f_{0}}\right)^{1 / 2}-\frac{T\left(f_{0}-\gamma_{0}\right)(s e(\hat{\alpha}))}{2 f_{0}{ }^{1 / 2} s}
$$

Where: $\hat{\alpha}$ estimate; $\tilde{t}_{\alpha}$ is the t-ratio of $\alpha ; \operatorname{se}(\hat{\alpha})$ is the coefficient standard error; T is the sample size or number of observations and $s$ is the standard error of the test regression. In addition, $\gamma_{0}$ is a consistent estimate of the error variance in the standard Dickey-Fuller equation (calculated as $(T-k) s^{2} / T$, where $\mathrm{k}$ is the number of repressors). The remaining term, $f_{0}$, is an estimator of the residual spectrum at frequency zero.

In our search for a long run relation, we use cointegration approach. When variables are cointegrated, the long-run relations are estimated by cointegrating vectors focusing on the order of integration of each series. Moreover, ARDL remains valid irrespective of the order of intergration. But ARDL procedure will collapse if any variable is $\mathrm{I}(2)$. Johansen $(1988 \mathrm{a}, 1991)$ derived distribution when the cointegrated system is parameterized as a vector error correction model (VECM). For a set of I(1) variables and a single cointegrating vector, Stock and Watson (1993) can be applied. The method has come to be known as the "dynamic OLS" (or GLS, as the case may be). The resulting "dynamic OLS" (respectively GLS) estimators are asymptotically equivalent to the Johansen estimator. In finite sample, these estimators perform better, relative to other asymptotically efficient estimators, when simple short-run dynamics is involved.

The DOLS procedure requires partial knowledge of the series expected to cointegrate and the orders of 
integration. With DOLS the problems associated with simultaneity, endogeneity and serial correlation are resolved by including leads and lags in small sample. The DOLS procedure is helpful if the series has different orders of lags (Stock-Watson, 1993). In the case of normal distribution the estimators have desirable properties as compared to Phillips and Perron (1988), Phillips and Loretan (1991) and Phillips and Moon (1999, 2001). In particular, the Engle-Granger's approach may not be satisfactory if in a multivariate case more than one cointegrating vector is present (Seddighi et al. 2000). Engle-Granger estimator suffers from a non-standard asymptotic distribution. Inferences on the parameters of the cointegrating vectors using DOLS estimator are efficient. Monte Carlo studies by Agrawal (2001) favor DOLS in estimating the long run relation. Predictive properties DOLS are better than the standard Engle-Granger (1987), Johansen (1988, 1991); Johansen-Juselius (1990) and Phillips \& Hansen (1990) procedures. As such we also apply the ARDL using the unrestricted error correction method. Following Faridul et al (2011) our model is specify thus:

$$
I N F_{t}=\psi_{0}+\sum_{i=1}^{p} \varphi_{t} I N F_{t-1}+\sum_{t=0}^{q} \eta_{t} U N P_{t-1}+\varepsilon_{t}
$$

We expect the coefficient of UNP to be negative and significant for the existence of Philips curve. Generally the short and the long run models follow thus:

$$
\begin{aligned}
\Delta \text { inf }=a_{0}- & b_{1} \text { inf }_{t-1}+c_{1} u n_{t-1}+d_{2} y_{t-1}+d_{3} m 2+ \\
& \sum_{i=1}^{p} e_{i} \Delta \text { inf }_{t-1}+\sum_{i=1}^{p} f_{i} \Delta u n_{t-1}+\sum_{i=1}^{p} g_{i} \Delta y_{t-1}+\sum_{i=1}^{p} h_{i} \Delta m 2_{t-1}+\varepsilon_{t} \ldots \ldots \ldots(4)
\end{aligned}
$$

In Equation-4, $1 \mathrm{~g}$ refers to a constant and $2 \mathrm{~g}$ to the long run parameter. The number of lags is denoted by $p ; k$ refers to lag length of the leads terms. The e refers to the error term. The selection of lags and leads is based on AIC.

In traditional approaches to cointegration, structural break in time series can be checked by Chow test. In ARDL, the CUSUM and CUSUMsq tests provide diagnosis for such information. For example, in Fig I and II, if the blue lines cross the red lines then structural break is likely. Based on the results obtained of this study, such outcome is unlikely. Also ARDL bounds test approach applies notwithstanding ambiguity in the order of integration7. This issue is relevant because in the presence of structural break in the data generating process, the traditional approaches may not capture cointegrating relation. This can potentially affect the outcome of the unit root test and the predictive powers (Leybourne and Newbold 2003; Perron, 1989, 1997)8. The ARDL approach is implemented by the following unrestricted error correction method (UECM) form (See Pesaran et al. 2001)):

$$
\Delta \text { inf }=a_{0}+\sum_{i=1}^{p} e_{i} \Delta \inf _{t-1}+\sum_{i=1}^{p} f_{i} \Delta u n_{t-1}+\sum_{i=1}^{p} g_{i} \Delta y_{t-1}+\sum_{i=1}^{p} h_{i} \Delta m 2_{t-1}+j E C M_{t-1}+\varepsilon_{t} \ldots(5)
$$

The ARDL model calculates $(p+1) \mathrm{k}$ number of regressions based an appropriate number of lags. The $\mathrm{p}$ indicates the number of lags in ARDL bounds testing and $\mathrm{k}$ is the number of actors in the model. In selecting lags, the minimum of AIC and SBC is used. The model has been subjected to sensitivity analysis to tests for serial correlation, functional form, normality, White heteroscedisticity, model specification and ARCH. CUSUM and CUSUMsq check for the stability of long and short run parameters. 


\section{Results and Discussions}

4.1 The Unit Root Test
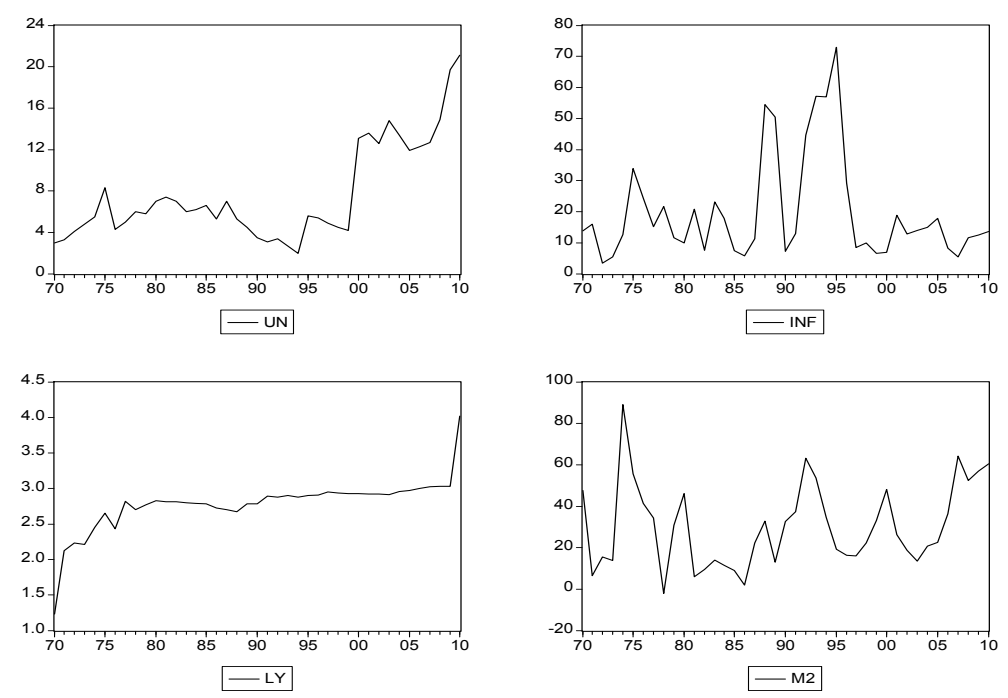

Figure 1. The initial clue about the likely nature of the time series under study

INF and M2 appear to fluctuate around a constant mean while both UN and LY appear to and upward trend over the period of study, suggesting perhaps that their mean have been changing. Therefore we can deduce that INF and M2 are stationary while UN and LY are not.

Table 1. Unit root test-ADF and PP

\begin{tabular}{|c|c|c|c|c|c|c|}
\hline Var & ADF Sta & C.V 5\% & Order & PP Sta & C.V 5\% & Order \\
\hline \multirow[b]{2}{*}{ INF } & -3.1360 & -3.5266 & \multirow[b]{2}{*}{$\mathrm{I}(1)$} & -2.9520 & -3.5266 & \multirow[b]{2}{*}{ I(1) } \\
\hline & -6.3668 & -3.5330 & & -12.635 & -3.5297 & \\
\hline \multirow[b]{2}{*}{$\mathbf{U N}$} & -1.0730 & -3.5266 & \multirow[b]{2}{*}{$\mathrm{I}(1)$} & -0.0038 & -2.9369 & \multirow[b]{2}{*}{ 1(1) } \\
\hline & -6.5303 & -3.5297 & & -6.5329 & -3.5297 & \\
\hline \multirow{2}{*}{ LY } & -5.2728 & -3.5266 & \multirow{2}{*}{$\mathbf{I}(\mathbf{0})$} & -5.2725 & -3.5266 & \multirow{2}{*}{$\mathbf{I}(\mathbf{0})$} \\
\hline & -5.6979 & -3.5297 & & -5.6305 & -3.5297 & \\
\hline \multirow{2}{*}{ M2 } & -3.8711 & -3.5266 & \multirow{2}{*}{$\mathbf{I}(\mathbf{0})$} & -3.9671 & -3.5266 & \multirow{2}{*}{$\mathbf{I}(\mathbf{0})$} \\
\hline & -7.7348 & -3.5297 & & -9.7711 & -3.5297 & \\
\hline
\end{tabular}

Source: Computed by the authors. Note: tests include intercept only.

Using the ADF and Philip Perron unit root tests, Table 1 confirm that while INF and UN are stationary at first difference; LY and M2 are stationary at level. This confirm that the variables in our study are integrated of both $\mathrm{I}(1)$ and $\mathrm{I}(0)$ which necessitate the adoption of ARDL model. However, the informal and formal unit root tests contradict each other. We now test for the significance of our model.

Table 2. Co integration test: bound test

\begin{tabular}{cccc}
\hline Model For Estimation & F-Statistics & Lag & Outcome \\
\hline $\mathrm{F}_{\mathrm{INF}}(\mathrm{INF})$ & $4.374149^{* *}$ & 2 & Co integration \\
Critical Bounds & Lower & Upper \\
$1 \%$ & 3.66 & 5.26 \\
$5 \%$ & 2.73 & & 3.92 \\
$10 \%$ & 2.31 & 3.35 \\
\hline
\end{tabular}

Note: The lag selection is based on AIC. 


\subsection{ARDL General to Specific Dynamic Ordinary Least Square (DOLS)}

From the robustness perspective, the Dynamic Ordinary Least Square result below shows that the coefficient of the ECM contains information about whether the past values of variables affect the current values of the variables under study.

$\begin{array}{cccc}\Delta \mathrm{INF}=0.7878194483 * \mathrm{UN}(-1) & -1.66209896^{*} \Delta \mathrm{UN}(-1) & -0.3559895048 * \mathrm{ECM}(-1) \\ 0.0836 & 0.2773 & 0.0075 & \text { Prob } \\ 0.442657 & 1.506691 & 0.125614 & \text { S.E } \\ 1.779752 & 1.779752 & -2.833985 & \text { t.Stat } \\ \mathrm{R}^{2}=0.193394 & & & \end{array}$

The absolute value of the coefficient of the error-correction term implies that about 35.6 percent of the disequilibrium in the Philips relations model is offset by short-run adjustment within a year. In this case, full adjustments are achieved, and take twelve months to complete the cycles. Thus, to maintain long run equilibrium between inflation and unemployment in Nigeria, it is important to reduce the existing disequilibrium over time.

As expected, the relation between the change in inflation rate and the unemployment rate from the specific analysis is negative in the short run - a low unemployment rate leads to an increase in the inflation rate and therefore an acceleration of the price level, hence the existence of Phillips curve. The specific result shows that a percentage increase in unemployment reduces inflation by 1.66 percent. However, the relation became positive in the long run since the coefficient of the first lag unemployment suggests that a percentage increase in unemployment increases inflation rate by 0.79 percent. More so the negative and significant coefficient of the first lag of INF (-0.3559895048) confirms a true long run relationship of the bound test result.

This negative short run relationship in Nigeria therefore supports the basic tenet of Philips curve of inverse relationship between unemployment and inflation rate. However, the long run result shows positive relationship between inflation and money supply and also economic growth. This inconsistent relationship is not expected since they are not in tandem with the theory. This can be as a result of continuous changes in the composition of the labour force consequent upon the demographic changes and random economic shocks such as currency devaluation, unanticipated increase in crude oil prices and various other policy inconsistencies in Nigeria.

These contradictory results might be as a result of the high level of natural rate of unemployment in Nigeria. Meanwhile, the recursive residual, the CUSUM and CUSUMsq tests suggest stability of the parameters.

\subsection{Stability Test}
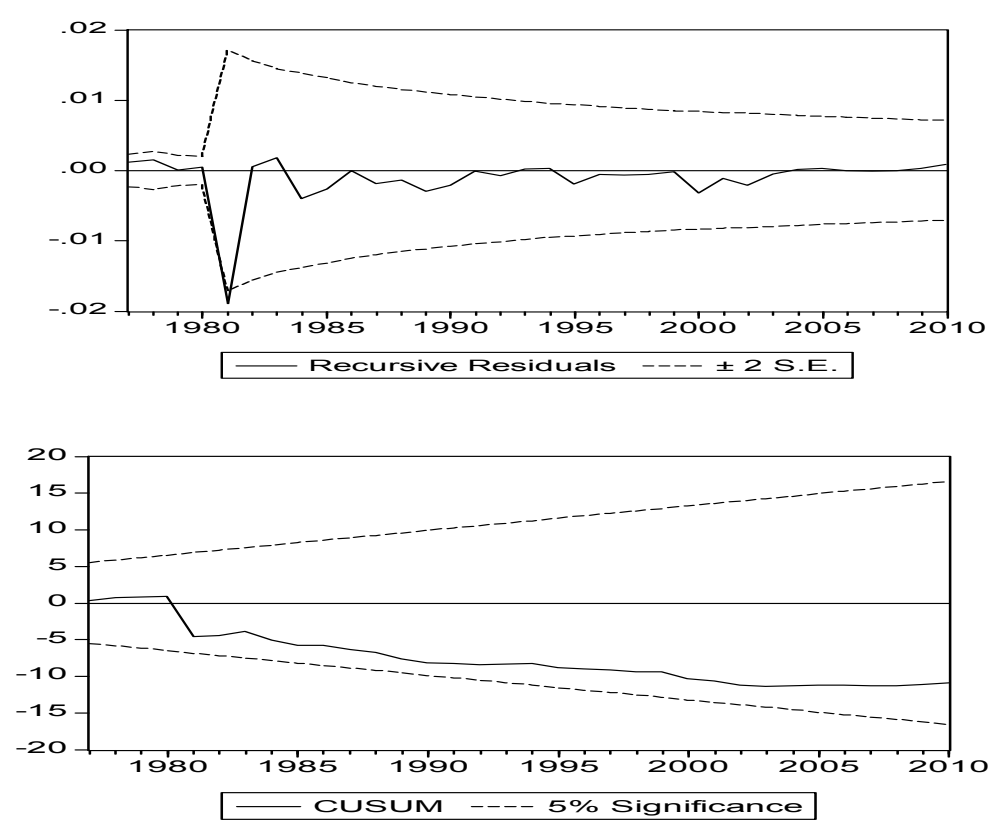


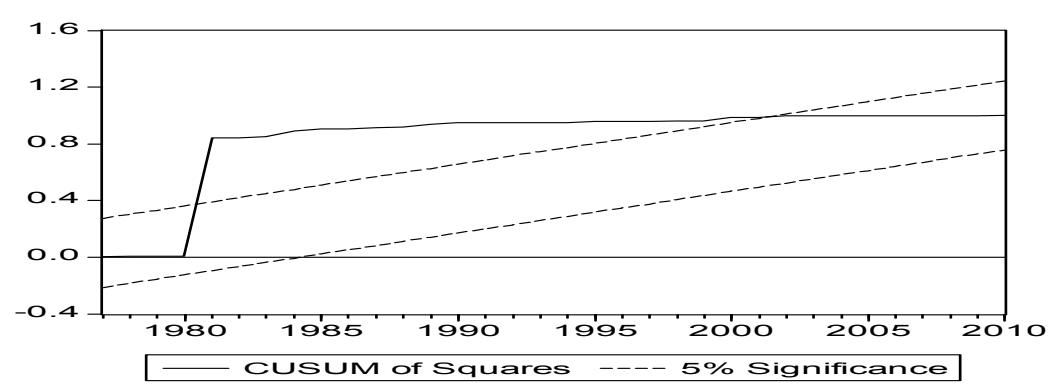

Figure 2. The recursive residuals and CUSUM of squares

Furthermore, issue of the stability of parameters of the model was considered. To this end we adopted the Bahmani-Oskooee and Shin (2002), as well as applying the cumulative sum of recursive residuals (CUSUM) to the residuals of the general model. For stability of short-run dynamics and long-run parameters of Philips relations, it is core that the residuals and cusum of squares stay within the 5 percent critical bound (represented by two straight lines whose equations are detailed in Brown, Durbin, and Evans, 1975, Section). As shown in the fig 2, neither the recursive residuals nor CUSUM of squares plots move outside the 5 percent critical lines. The result is suggestive of coefficient stability, therefore, we can safely conclude that the estimated parameters for the short-run dynamics and long-run of inflation function exists over the entire sample periods since residual result shows the future tendency of further stability. However, as with the CUSUM test, movement outside the critical line between 1981 and 2002 is suggestive of parameter or variance instability. Meanwhile, the test does not tell us the source of the instability that whether on account of intercept or on account of slope. This issue can be address in feature research. Meanwhile, the cumulative sum of squares is generally within the 5 percent significant lines, after 2002 suggesting that the residual variance is somewhat recently stable, corroborating the other stability test results.

The continued existence of this observed relationship implies that policy makers could only choose between inflation or unemployment in the course of macroeconomic management. It means that high levels of employment can only be obtained by tolerating a high rate of inflation. Conversely Nigeria government can achieve low rate of inflation only at the cost of high unemployment rate. Our result revealed the twin evil of macroeconomic with which both unemployment and inflation have being derived at least in the short run.

\section{Conclusion}

The paper estimates a Philips Curve for Nigeria using ARDL General to Specific bounds testing and DOLS approaches. ADF unit root test is applied to check the order of integration. Results establish co integration between inflation, unemployment, money supply and real gross domestic product for Nigeria suggesting a long run relationship over the study period. The results from General to specific OLS and DOLS confirm a theoretical trade off between inflation and unemployment variables in the short run but prove otherwise statistically in the long run. The result shows that while inflation is increasing unemployment also increase in the long run which implies that Phillips curve does not exists for Nigeria in the long run. This suggests that policy makers cannot use the trade-off relation in choosing appropriate strategy. They should be careful in adopting a monetary policy that would keep inflation at a politically acceptable level in Nigeria. These contradictory results might be as a result of the high level of natural rate of unemployment in Nigeria. Rational policy making therefore means that Nigeria policy makers would have to settle for that combination that minimizes the twin macroeconomic evils.

Meanwhile, the recursive residual, the CUSUM and CUSUMsq tests suggest stability of the parameters in the long run.

\section{References}

Agrawal, P. (2001). The relation between saving and growth: Cointegration and causality evidence from Asia. Applied Economics, 33, 499-513. http://dx.doi.org/10.1080/00036840122210

Akerlof, G. A., Dickens, W. T., \& Perry, G. L. (1996). The macroeconomics of low inflation. Brookings Papers on Economic Activity, 1, 1-76. http://dx.doi.org/10.2307/2534646

Akerlof, G. A., Dickens, W. T., \& Perry, G. L. (2000). Near-rational wage and price setting and the long run Phillips Curve. Brookings Papers on Economic Activity, 1, 1-60. http://dx.doi.org/10.1353/eca.2000.0001 
Atkeson, A., \& Ohanian, L. E. (2001). Are Phillips Curves useful for forecasting inflation? FRB Minneapolis Quarterly Review, 2-11.

Bahmani-Oskooee, M., \& Nasir, A. (2004). ARDL approach to test the productivity bias hypothesis. Review of Development Economics Journal, 8, 483-488. http://dx.doi.org/10.1111/j.1467-9361.2004.00247.x

Bhanthumnavin, K. (2002). The Phillips Curve in Thailand. St. Antony's College, University of Oxford. Retrieved from www.ecomod.net/conferences/ecomod2002

Brouwer, G. D., \& Ericsson, N. R. (1998). Modeling inflation in Australia. Journal of Business and Economic Statistics, 16, 433-449.

Dammak, T. B., \& Boujelbene, Y. (2009). The nature of the Phillips Curve in Tunisia: New empirical evidence. International Journal of Monetary Economics and Finance, 2, 126-143. http://dx.doi.org/10.1504/IJMEF.2009.024836

Del Boca, A. M., Fratianni, F. S., \& Trecroci, C. (2008). The Phillips Curve and the Italian lira, 1861-1998. Working Paper, Department of Economics, University of Brescia.

Demers, F. (2003). The Canadian Phillips Curve and regime shifting. Bank of Canada Working Paper 2003-32, Bank of Canada, Ottawa, Canada.

Eliasson, A. (2001). Is the short-run phillips curve nonlinear? Empirical evidence for Australia, Sweden and the United States. Sveriges Riksbank Working Paper-124, Stockholm School of Economics, Department of Economic Statistics.

Engle, R. F., \& Granger, C. W. J. (1987). Cointegration and error correction: Representation, estimation and testing. Econometrica, 55(2), 251-276. http://dx.doi.org/10.2307/1913236

Faridul, I. S., Muhammad, S., \& Muhammad, N. (2011). Philips Curve in a small open economy: A time series exploration of North Cyprus. MPRA Paper No. 28397.

Franz, W. (2005). Will the (German) NAIRU please stand up?. German Economic Review, 2, 131-153. http://dx.doi.org/10.1111/j.1465-6485.2005.00124.x

Furuoka, F. (2007). Does the Phillips Curve really exist? New empirical evidence from Malaysia. Economics Bulletin, 5, 1-14.

Gali, J., Gertler, M., \& Lopez-Salido, J. D. (2005). Robostness of the estimates of the hypbrid New Keynesian Philips Curve. Journal of Monetary Economics, 52, 1107-1118. http://dx.doi.org/10.1016/j.jmoneco.2005.08.005

Gordon, R. J. (1971). Price in 1970: The horizontal Phillips Curve. Brookings Papers on Economic Activities, 3, $449-458$.

Graham, L., \& Snower, D. (2002). The return of the long-run Phillips Curve. Working Paper, Department of Economics, Birkbeck College, University of London.

Hansen, M., \& Pancs, R. (2001). The latvian labour market transition: The Beveridge and Phillips Curve as indicators of normalisation. Riga: Euro Faculty.

Islam, F. K., Hassan, M. M., \& Rahman, M. (2003). The empirics of US Phillips Curve: A revisit. American Business Review, 20(1), 107-112.

Johansen, S. (1988). Statistical analysis of cointegration vector. Journal of Economic Dynamics and Control, 12(2/3), 231-254. http://dx.doi.org/10.1016/0165-1889(88)90041-3

Karanassou, M., Sala, H., \& Snower, D. J. (2003). The European Philips Curve: Does the NAIRU exist? Applied Economics Quarterly, (2), 93-121.

Karanassou, M., Sala, H., \& Snower, D. J. (2005). A reappraisal of the inflation-unemployment tradeoff. European Journal of Political Economy, 21, 1-32. http://dx.doi.org/10.1016/j.ejpoleco.2004.02.003

Karanassou, M., Sala, H., \& Snower, D. J. (2008). The evolution of inflation and unemployment: Explaining the $\begin{array}{lllll}\text { roaring nineties. Australian } & \text { Economic }\end{array}$ http://dx.doi.org/10.1111/j.1467-8454.2008.00353.x

Karanassou, M., Sala, H., \& Snower, D. J. (2010). Phillips Curves and unemployment dynamics: A critique and a holistic perspective. Journal of Economic Surveys, 24(1), 1-51. http://dx.doi.org/10.1111/j.1467-6419.2009.00598.x 
Kustepeli, Y. (2005). A comprehensive short-run analysis of a (possible) Turkish Phillips Curve. Applied Economics, 37, 581-91. http://dx.doi.org/10.1080/000368404200030749

Leybourne, S. J., \& Newbold, P. (2003). Spurious rejections by cointegration tests induced by structural breaks. Applied Economics, 35(9), 1117-21. http://dx.doi.org/10.1080/0203684032000082068

Lipsey, R. G. (1960). The relation between unemployment and the rate of change of money wage rate in United Kingdom 1962-1951. Econometrica, 27, 1-12.

Lucas, R. E. Jr. (1972). Expectations and the neutrality of money. Journal of Economic Theory, 4(2), 103-24. http://dx.doi.org/10.1016/0022-0531(72)90142-1

Lucas, R. E. Jr. (1973). Some international evidence on output-inflation tradeoffs. American Economic Review, 63(3), 326-334.

Lucas, R. E. Jr. (1976). Econometric policy evaluation: A critique. Carnegie-Rochester Series on Public Policy, 1, 19-46. http://dx.doi.org/10.1016/S0167-2231(76)80003-6

Malinov, M. J., \& Sommers, P. M. (1997). A new line on the Phillips Curve. Social Science Quarterly, 78(3), 740-746.

Mankiw, N. G., (2001). The inexorable and mysterious tradeoff between inflation and unemployment. Economic Journal, 45-61. http://dx.doi.org/10.1111/1468-0297.00619

Narayan, P. K. (2005). The saving and investment nexus for China: Evidence from cointegration tests. Applied Economics, 37, 1979-1990. http://dx.doi.org/10.1080/00036840500278103

Niskanen, W. A. (2002). On the death of Phillips Curve. Cato Journal, 22, 193-98

Okun, A. M. (1975). Inflation: Its mechanics and welfare costs. Brookings Papers On Economics Activity, 2, 351-390. http://dx.doi.org/10.2307/2534106

Onder, A. O. (2004). Forecasting inflation in emerging market markets by using the Philips Curves and alternative time series model. Emerging Markets Finance and Trade, 40, 71-82.

Ormerod, P., Rosewell, B., \& Phelps, P. (2013). Inflation/unemployment regimes and the instability of the Phillips Curve. Applied Economics, 45(12), 1519-1531. http://dx.doi.org/10.1080/00036846.2011.628299

Paul, B. P. (2009). In search of the Phillips Curve for India. Journal of Asian Economics, 20, 479-488. http://dx.doi.org/10.1016/j.asieco.2009.04.007

Pesaran, M. H., Shin, Y., \& Smith, R. J. (2001). Bonds testing approaches to the analysis of level relationships. Journal of Applied Econometrics, 16, 289-326. http://dx.doi.org/10.1002/jae.616

Phelps, E. (1967). Phillips curve, expectation of inflation, and optimal inflation over time. Economica, 34, 254 281. http://dx.doi.org/10.2307/2552025

Philips, A. W. (1958). The relationship between unemployment and the rate of change of money wage rates in the United Kingdom. Econometrica, 25, 258-299.

Phillips, P. C. B., \& Hansen, B. E. (1990). Statistical inference in instrumental variables regression with I(1) processes. Reviews of Economic Studies, 57, 99-125. http://dx.doi.org/10.2307/2297545

Phillips, P. C. B., \& Loretan, M. (1991). Estimating long-run economic equilibria. Review of Economic Studies, 58, 407-436. http://dx.doi.org/10.2307/2298004

Phillips, P. C. B., \& Moon, H. R. (1999). Linear regression limit theory for nonstationary panel data. Econometrica, 67, 1057-1111. http://dx.doi.org/10.1111/1468-0262.00070

Phillips, P. C. B., \& Moon, H. R. (2001). Nonstationary panel data analysis: An overview and some recent developments. Econometric Reviews, 19(3), 263-86. http://dx.doi.org/10.1080/07474930008800473

Phillips, P., \& Perron, P. (1988). Testing for a unit root in time series regression. Biometrica, 75(3), 335-346. http://dx.doi.org/10.1093/biomet/75.2.335

Reichel, R. (2004). On the death of the Philip Curve: Further evidence. Cato Jourtnal, 24, 341-348.

Rudd, J., \& Whelan, K. (2005). New tests of the New Keynesian Philips Curve. Journal of Monetary Economnics, 52, 1167-1181. http://dx.doi.org/10.1016/j.jmoneco.2005.08.006

Russell, B., \& Banerjee, A. (2008). The long-run Phillips Curve and non-stationary of inflation. Journal of Macroeconomics, 30, 1792-1815. http://dx.doi.org/10.1016/j.jmacro.2007.11.001 
Schreiber, S., \& Wolters, J. (2007). The long-run Phillips Curve revisited: Is the NAIRU framework data-consistent?. Journal of Macroeconomics, 29, 355-367. http://dx.doi.org/10.1016/j.jmacro.2005.08.003

Solow, R. M. (1970). Dicussion of R.J Gordon's recent acceleration of Philips Curve in Malaysia. Discussion Paper-39, Monash University.

Stock, J. H., \& Watson, M. (1993). A simple estimator of cointegrating vectors in higher order integrated system. Econometrica, 61, 783-820. http://dx.doi.org/10.2307/2951763

Tang, C. F., \& Lean, H. H. (2007). The stability of Phillips Curve in Malaysia. Discussion Paper-39, Monash University.

Turner, D., \& Seghezza, E (1999). Testing for a common OECD Phillips Curve. Economics Department Working Paper No. 219, OECD. http://dx.doi.org/10.1787/340107434541

Turner, P. (1997). The Phillips Curve, parameter instability and the lucas critique. Applied Economics, 29(1), $7-$ 10. http://dx.doi.org/10.1080/000368497327344

\section{Appendix}

Appendix 1. ARDL specific dynamic OLS

Dependent Variable: DINF

Method: Least Squares

Date: 06/02/07 Time: 21:46

Sample(adjusted): 19722010

Included observations: 39 after adjusting endpoints

\begin{tabular}{ccccc}
\hline Variable & Coefficient & Std. Error & t-Statistic & Prob. \\
\hline INF(-1) & -0.355990 & 0.125614 & -2.833985 & 0.0075 \\
UN(-1) & 0.787819 & 0.442657 & 1.779752 & 0.0836 \\
DUN(-1) & -1.662099 & 1.506691 & -1.103145 & 0.2773 \\
R-squared & 0.193394 & Mean dependent var & 0.269231 \\
Adjusted R-squared & 0.148582 & S.D. dependent var & 19.49935 \\
S.E. of regression & 17.99250 & Akaike info criterion & 8.691591 \\
Sum squared resid & 11654.29 & Schwarz criterion & 8.819557 \\
Log likelihood & -166.4860 & \multicolumn{2}{c}{ Durbin-Watson stat } & 2.053761 \\
\hline
\end{tabular}

Appendix 2. ARDL wald test

Wald Test:Equation: Untitled

\begin{tabular}{|c|c|c|c|}
\hline Test Statistic & Value & df & Probability \\
\hline F-statistic & 4.374149 & $(4,31)$ & 0.0064 \\
\hline Chi-square & 17.49659 & 4 & 0.0015 \\
\hline \multicolumn{4}{|c|}{ Null Hypothesis Summary: } \\
\hline \multicolumn{2}{|c|}{ Normalized Restriction $(=0)$} & Value & Std. Err. \\
\hline \multicolumn{2}{|c|}{$\begin{array}{l}C(1) \\
C(2)\end{array}$} & -0.666135 & 0.161882 \\
\hline $\mathrm{C}(2$ & & 0.674968 & 392.4126 \\
\hline \multicolumn{2}{|c|}{$\mathrm{C}(3)$} & 4.067210 & 36.59857 \\
\hline \multirow{2}{*}{\multicolumn{4}{|c|}{$\begin{array}{ll}C(4) & -1.282848 \\
\text { Restrictions are linear in coefficients. }\end{array}$}} \\
\hline & & & \\
\hline Test Statistic & Value & df & Probability \\
\hline F-statistic & 2.688363 & $(4,31)$ & 0.0494 \\
\hline Chi-square & 10.75345 & 4 & 0.0295 \\
\hline \multicolumn{4}{|c|}{ Null Hypothesis Summary: } \\
\hline \multicolumn{2}{|c|}{ Normalized Restriction $(=0)$} & Value & Std. Err. \\
\hline \multicolumn{2}{|c|}{$C(1)$} & 0.315582 & 0.106607 \\
\hline \multicolumn{2}{|c|}{$C(2)$} & 0.018069 & 0.023374 \\
\hline \multicolumn{2}{|c|}{$C(3)$} & 10.05978 & 46.32704 \\
\hline $\mathrm{C}(4$ & & -1.265454 & 4.312378 \\
\hline \multicolumn{4}{|l|}{ Restrictions are lir } \\
\hline
\end{tabular}


Appendix 3. ARDL general dynamic OLS

Dependent Variable: DINF

Method: Least Squares

Date: 06/01/07 Time: 16:50

Sample(adjusted): 1972-2010

Included observations: 39 after adjusting endpoints

\begin{tabular}{ccccc}
\hline Variable & Coefficient & Std. Error & t-Statistic & Prob. \\
\hline INF(-1) & -0.666135 & 0.161882 & -4.114936 & 0.0003 \\
LM2(-1) & 0.674968 & 392.4126 & 0.001720 & 0.9986 \\
LY(-1) & 4.067210 & 36.59857 & 0.111130 & 0.9122 \\
UN(-1) & -1.282848 & 0.993525 & -1.291208 & 0.2062 \\
DLM2(-1) & 1676.203 & 898.4109 & 1.865742 & 0.0716 \\
DLY(-1) & -157.5581 & 84.42141 & -1.866328 & 0.0715 \\
DUN(-1) & -0.346899 & 1.523962 & -0.227630 & 0.8214 \\
C & -26.39144 & 537.2538 & -0.049123 & 0.9611 \\
R-squared & 0.403828 & Mean dependent var & 0.269231 \\
Adjusted R-squared & 0.269209 & S.D. dependent var & 19.49935 \\
S.E. of regression & 16.66928 & Akaike info criterion & 8.645694 \\
Sum squared resid & 8613.810 & Schwarz criterion & 8.986937 \\
Log likelihood & -160.5910 & F-statistic & 2.999780 \\
Durbin-Watson stat & 1.722052 & Prob(F-statistic) & 0.015897 \\
\hline
\end{tabular}

\section{Copyrights}

Copyright for this article is retained by the author(s), with first publication rights granted to the journal.

This is an open-access article distributed under the terms and conditions of the Creative Commons Attribution license (http://creativecommons.org/licenses/by/3.0/). 